\title{
Effects of ovariectomy and genotype on bioactive FSH in plasma and pituitary of Booroola ewes
}

\author{
D. J. Phillips, N. L. Hudson and K. P. McNatty \\ Wallaceville Animal Research Centre, PO Box 40063, Upper Hutt, New Zealand
}

\begin{abstract}
Blood samples were collected for 13 days before and 20 days after ovariectomy from carrier (BB) and non-carrier $(++)$ ewes of the Booroola $\mathrm{Fec}^{\mathrm{B}}$ gene $(n=12$ per genotype), at known stages of the oestrous cycle, after which the pituitary glands from these ewes were recovered. Pituitary glands were also collected from cyclic ewes (about day $12 ; n=5$ per genotype) to compare the effects of ovariectomy on pituitary gonadotrophins. Plasma samples and pituitary extracts were assayed for bioactive (B) FSH, immunoreactive (I) FSH and I-LH. Overall, BB ewes had significantly $(P<0.05)$ higher plasma I-FSH concentrations than did ++ ewes before ovariectomy; the mean value was higher on 16 of the 17 days of the oestrous cycle $(P<0.01)$. For B-FSH, there were no overall genotypic differences, although the mean for the $\mathrm{BB}$ ewes was significantly higher on 13 of the 17 days of the oestrous cycle $(P<0.05)$, and significantly $(P<0.05)$ higher between days 13 and 16 . No genotypic differences were noted for the plasma bioactive:immunoreactive (B:I) ratio for FSH before ovariectomy. After ovariectomy, there were significant $(P<0.001)$ increases in plasma for B-FSH, I-FSH and I-LH and a significant $(P<0.05)$ decrease in the B:I ratio for $\mathrm{FSH}$, irrespective of genotype. Furthermore, BB ewes had significantly $(P<0.05)$ higher overall concentrations of B-FSH and plasma B:I ratios after ovariectomy than did + + ewes; overall I-FSH concentrations were not significantly different between genotypes but the BB ewes had a higher mean value on 17 of the 20 days after ovariectomy $(P<0.001)$. With respect to pituitary FSH, there were no significant effects of genotype or ovariectomy on B-FSH or I-FSH contents or concentrations. No genotypic differences were noted in either plasma or pituitary I-LH, except for a higher pituitary I-LH content in BB ewes after ovariectomy. These data show that both ovariectomy and the $\mathrm{Fec}^{\mathrm{B}}$ gene cause qualitative and quantitative changes in plasma FSH, but have little effect on pituitary $\mathrm{FSH}$.
\end{abstract}

\section{Introduction}

Increases in plasma immunoreactive (I)-FSH and I-LH concentrations after castration have been documented in ewes (e.g. Lahlou-Kassi et al., 1984; Martin et al., 1986; Montgomery et al., 1987). The precise mechanisms responsible for these increases are not entirely understood. After ovariectomy, the concentration of ovine gonadotrophins in the pituitary gland (Moss et al., 1981), and the half-life of endogenous forms (Montgomery et al., 1984; Fry et al., 1987; Robertson et al., 1991) increase. Presumably both of these factors contribute to the higher concentrations of plasma gonadotrophins after castration. Less is known about changes in the bioactivity of FSH and LH following ovariectomy, and available data are confined to pituitary extracts. In heifers, ovariectomy results in a shift towards the production of more basic isoforms of FSH in the pituitary gland (Stumpf et al., 1992), whereas in ewes (Robertson et al., 1991) and rats (Robertson et al., 1982) no changes were noted in the electrophoretic profiles of pituitary FSH following ovariectomy. In all three species, the above studies reported Received 16 October 1992. that ovariectomy resulted in a shift towards more basic isoforms of $\mathrm{LH}$.

In common with other strains of sheep, ewes that are homozygous carriers (BB) of the Booroola fecundity gene $\left(\mathrm{Fec}^{\mathrm{B}}\right.$ ) exhibit increases in plasma I-FSH and I-LH concentrations after castration (McNatty et al., 1989; McNatty et al., 1991). Although it is generally accepted that ovary-intact BB ewes have higher plasma concentrations of I-FSH than do non-carrier $(++)$ ewes (McNatty et al., 1991), the issue of gene-specific differences in plasma FSH and LH concentrations following ovariectomy remains unresolved. In one study (McNatty et al., 1989), plasma I-FSH and I-LH concentrations were usually higher in ovariectomized BB ewes than in ovariectomized ++ ewes, whereas data from another study, reported in a review by McNatty et al. (1991), showed no gene-specific differences in plasma gonadotrophin concentrations at several time-points after ovariectomy.

The aim of the present study was to determine B-FSH, I-FSH and I-LH concentrations in the plasma and pituitary glands of ewes before and after ovariectomy, using both homozygous carriers $(\mathrm{BB})$ and non-carriers $(++)$ of the $\mathrm{Fec}^{\mathrm{B}}$ gene. 


\section{Materials and Methods}

\section{Animals and treatments}

The experimental procedures reported in this study were carried out in accordance with the 1987 Animal Protection (Codes of Ethical Conduct) Regulations of New Zealand after approval was granted by the Animal Ethics Committee of the Wallaceville Animal Research Centre. The study was carried out in May-June 1991, during the middle of the breeding season.

The genotypes of all ewes, with respect to the $\mathrm{Fec}^{\mathrm{B}}$ gene, were determined on the basis of controlled matings and ovulation rate records. Homozygous (BB) carriers were the offspring of $\mathrm{BB}$ rams and $\mathrm{BB}$ ewes, and had been recorded as having an ovulation rate of at least five on three separate occasions, whereas non-carriers $(++)$ were the offspring of ++ rams and ++ ewes and had three ovulation records of two or less (Davis et al., 1982). The BB ewes in this study were derived from ten different sires, and the ++ ewes from six different sires.

Twenty-four Merino or Romney ewes $(n=12$ per genotype) were selected so that the $\mathrm{BB}$ and ++ groups were matched for breed and age. The mean \pm SEM age of the ewes was $6.8 \pm 0.3$ years $(n=24)$; liveweights were not recorded. For all ewes the dates of oestrus were known, but oestrous cycles were not synchronized before the study began. Blood samples were collected by jugular venepuncture at 09:00 h daily for 14 consecutive days. On the fourteenth day, the ewes underwent ovariectomy using procedures described by McNatty et al. (1989). The mean ( \pm SEM) day of the oestrous cycle at the time of ovariectomy was $6.3 \pm 1.1$ for the $B B$ group and $9.6 \pm 0.5$ for the ++ group. Daily blood samples were collected for a further 20 days after ovariectomy, after which the ewes were killed by cervical exsanguination. Pituitary glands were collected within $5 \mathrm{~min}$ of death, frozen in liquid nitrogen, and stored at $-70^{\circ} \mathrm{C}$ until processing. Another group of cyclic ewes ( $n=5$ per genotype) was killed between days 10 and 13 of the oestrous cycle; the mean \pm SEM day of the oestrous cycle was $12.8 \pm 0.2$ for the BB group and $11.2 \pm 0.6$ for the ++ group. A blood sample and the pituitary gland were collected from each ewe at the time of death and stored as above.

All blood samples were centrifuged at $4000 \mathrm{~g}$ at room temperature for $10 \mathrm{~min}$ within $30 \mathrm{~min}$ of collection and the plasma obtained was stored at $-20^{\circ} \mathrm{C}$ until assayed. Individual pituitary glands were thawed, weighed and extracted as described by Robertson et al. (1982); extracts were stored at $-20^{\circ} \mathrm{C}$ until assayed. Plasma samples and pituitary extracts were assayed for $\mathrm{I}-\mathrm{FSH}, \mathrm{B}-\mathrm{FSH}$ and $\mathrm{I}-\mathrm{LH}$.

\section{Assays}

Plasma and pituitary concentrations of I-FSH were measured using a radioimmunoassay kit supplied by The National Hormone and Pituitary Program of the National Institute of Diabetes and Kidney Diseases (NIDDK), as described by McNatty et al. (1989). The ovine (o)FSH used for iodination was NIAMDD-oFSH-I-I; the reference preparation was NIAMDDoFSH-RP-1 (biopotency $75 \times$ NIH-FSH-S1) and the oFSH antiserum was NIAMDD-anti-oFSH-1. The assay sensitivity was
$0.1 \mathrm{ng} \mathrm{ml}^{-1}$ and the intra- and interassay CVs were 4 and $8 \%$, respectively.

Plasma and pituitary concentrations of B-FSH were measured using the production of oestradiol in vitro from Sertoli cells isolated from immature male rats (Padmanabhan et al., 1987). The only modification to the published procedure was the use of a $0.5 \mathrm{ml}$ substrate incubation volume instead of $1 \mathrm{ml}$. The radioimmunoassay used to detect the production of oestradiol (McNatty et al., 1984) had an assay sensitivity of $5 \mathrm{pg} \mathrm{ml}^{-1}$, and the intra- and interassay CVs were both $<10 \%$. The reference standard used in the in vitro bioassay was NIAMDD-oFSHRP-1, the assay sensitivity was $1 \mathrm{ng} \mathrm{ml} l^{-1}$ and the intra- and interassay CVs were 8 and $14 \%$, respectively. As it is impractical to assay large numbers of samples using this assay, only samples from two days out of three were assayed for B-FSH concentrations.

The I-LH assay was as described by McNatty et al. (1989). The oLH used for iodination was NIADDK-oLH-I-3; the reference preparation was NIAMDD-oLH-24 (biopotency $2.3 \times$ NIH-LH-S1); and the oLH antiserum was raised at Wallaceville as described by McNatty et al. (1987). The assay sensitivity was $0.1 \mathrm{ng} \mathrm{ml}^{-1}$ and the intra- and interassay CVs were 5 and $7 \%$, respectively.

\section{Statistical analyses}

All the data were analysed after log transformation, to correct for heterogeneity of variance. In addition, the B:I ratio, being the quotient of two variables that each approximate a normal distribution, cannot itself approximate a normal distribution. However, a log transformation of the B:I ratio overcomes this problem. All analyses were by Student's $t$ test, unless otherwise stated. For each ewe, a mean plasma concentration was calculated for B-FSH, I-FSH, B:I ratio and I-LH both before and after ovariectomy. Effects of ovariectomy and genotype on the group means of these individual ewe values were analysed, and the distribution of values was compared using Box and Whisker plots (Emerson and Strenio, 1983). The number of days that each genotype had higher mean plasma I-FSH, B-FSH, FSH B:I ratio or I-LH was tested using the binomial test (Zar, 1974). Before ovariectomy, data were also expressed relative to the day of the oestrous cycle (day $0=$ oestrus). Genotypic differences were also tested for significance between days 13 and 16 . Mean concentrations and total contents of pituitary I-FSH, $\mathrm{B}-\mathrm{FSH}$ and I-LH were analysed for differences attributable to genotype and ovariectomy.

\section{Results}

\section{Parallelism of plasma and pituitary samples in the FSH bioassay}

Increasing volumes of plasma (Fig. 1) or pituitary extract (data not shown) from both genotypes with or without ovaries ran parallel with the oFSH standard in the in vitro bioassay.

\section{Plasma gonadotrophin concentrations before ovariectomy}

For I-FSH concentrations, the daily mean FSH value was higher in the $\mathrm{BB}$ ewes than that for the ++ group on 16 of the 17 days of the oestrous cycle $(P<0.01)$ (Fig. 2). Overall, mean 


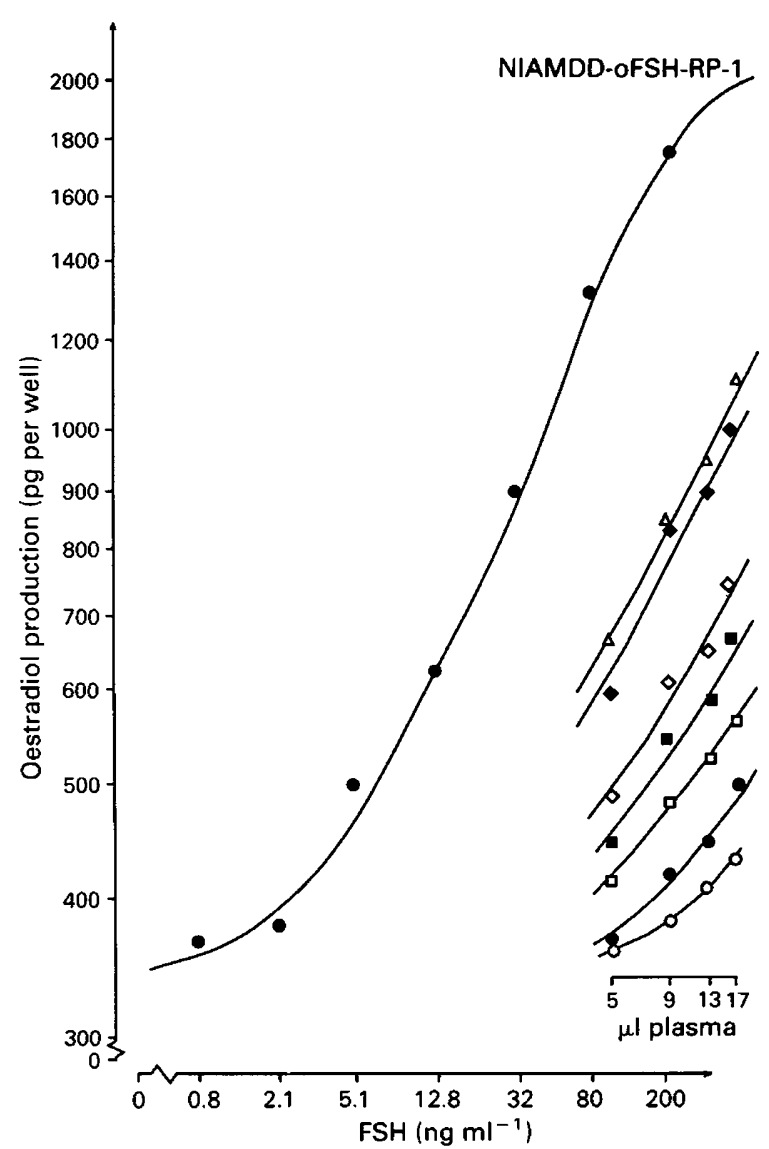

Fig. 1. Parallelism between the NIAMDD-oFSH-RP-1 standard and aliquots of plasma from individual ewes of either genotype before and after ovariectomy in the follicle-stimulating hormone (FSH) bioassay.

( \pm SEM) I-FSH concentrations before ovariectomy were significantly $(P<0.05)$ higher in the BB group than in the ++ group (1.6 \pm 0.2 versus $1.2 \pm 0.1 \mathrm{ng} \mathrm{ml}^{-1}$; Fig. 3). For B-FSH, overall concentrations were not significantly different between the two genotypes $\left(3.5 \pm 0.4\right.$ versus $\left.2.8 \pm 0.4 \mathrm{ng} \mathrm{ml}^{-1}\right)$. However, the $\mathrm{BB}$ ewes had a higher mean B-FSH concentration than did the ++ ewes on 13 of the 17 days $(P<0.05)$ of the oestrous cycle. In addition, the BB group had significantly $(P<0.05)$ higher mean concentrations of both B-FSH and I-FSH from days 13 to 16 (i.e. late luteal-follicular phase) of the oestrous cycle. No genotypic differences were detected in plasma B:I ratio for FSH or in I-LH concentrations before ovariectomy, for either the overall mean values or in the number of days that either genotype had the higher mean value.

In the ovary-intact ewes from which pituitary glands were recovered, plasma I-FSH concentrations at the time of death were significantly $(P<0.01)$ higher in the $\mathrm{BB}$ ewes than in the ++ ewes $\left(2.1 \pm 0.2\right.$ versus $\left.0.9 \pm 0.2 \mathrm{ng} \mathrm{ml}^{-1}\right)$, whereas I-LH concentrations were not significantly different between genotypes $\left(0.3 \pm 0.1\right.$ versus $\left.0.2 \pm 0.1 \mathrm{ng} \mathrm{ml}^{-1}\right)$. B-FSH concentrations were not measured in these samples.

\section{Plasma gonadotrophin concentrations after ovariectomy}

Irrespective of genotype, I-FSH, B-FSH and I-LH concentrations were significantly $(P<0.001)$ higher after ovariectomy
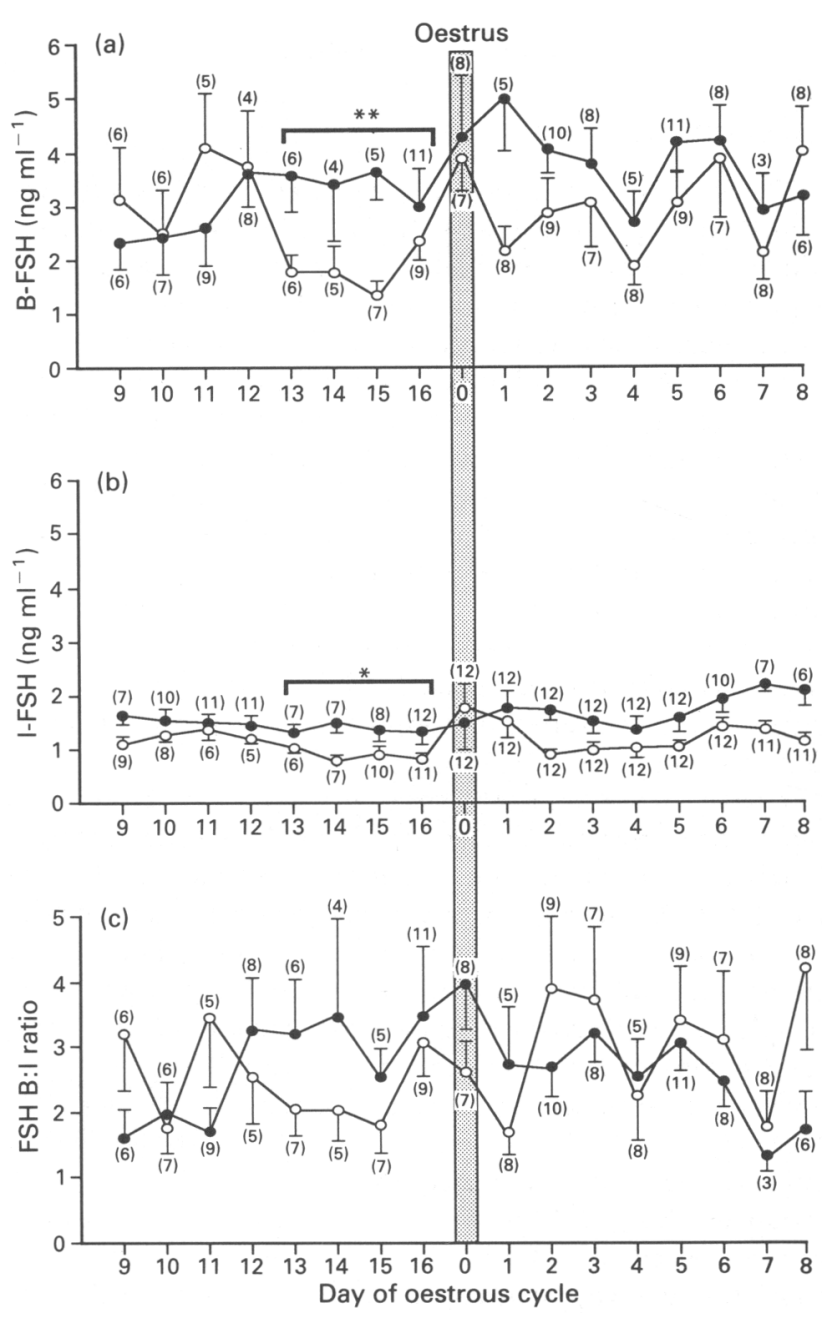

Fig. 2. Daily mean ( $\pm \mathrm{SEM} ; n$ per point given in brackets) concentrations of plasma (a) bioactive (B) FSH and (b) immunoreactive (I) FSH, and (c) plasma bioactive:immunoreactive (B:I) ratios for $\mathrm{BB}(\mathrm{O})$ and $++(O)$ ewes before ovariectomy, expressed relative to the day of oestrus (day 0 ). Significant differences between the genotypes between days 13 and 16 are shown by asterisks $\left({ }^{*} P<0.05,{ }^{* *} P<0.01\right.$; Student's $t$ test). Note that the axes scales for B-FSH and I-FSH are identical. Oestrus is shown by the stippled bar.

(Fig. 3). However, in both genotypes the overall plasma B:I ratio for FSH decreased significantly $(P<0.05)$ compared with preovariectomy values. The BB group had higher mean concentrations of I-FSH on 17 of the 20 days of sampling after ovariectomy $(P<0.001$; Fig. 4$)$, but overall the group means after ovariectomy were not significantly different $(7.2 \pm 0.6$ versus $6.7 \pm 0.3 \mathrm{ng} \mathrm{ml}^{-1}$ ). For B-FSH, the $\mathrm{BB}$ group had higher concentrations compared with the ++ group on all days after ovariectomy $(P<0.001)$. Overall, the BB ewes had significantly $(P<0.05)$ higher B-FSH concentrations after ovariectomy than did the ++ group $(13.1 \pm 1.2$ versus $9.7 \pm$ $\left.0.7 \mathrm{ng} \mathrm{ml}^{-1}\right)$. Similarly, plasma B:I ratios for FSH were higher on all days after ovariectomy in the BB ewes $(P<0.001)$. Overall, the plasma $B: I$ ratio was significantly $(P<0.05)$ higher in the $B B$ ewes after ovariectomy $(1.8 \pm 0.1$ versus $1.4 \pm 0.1)$. No 

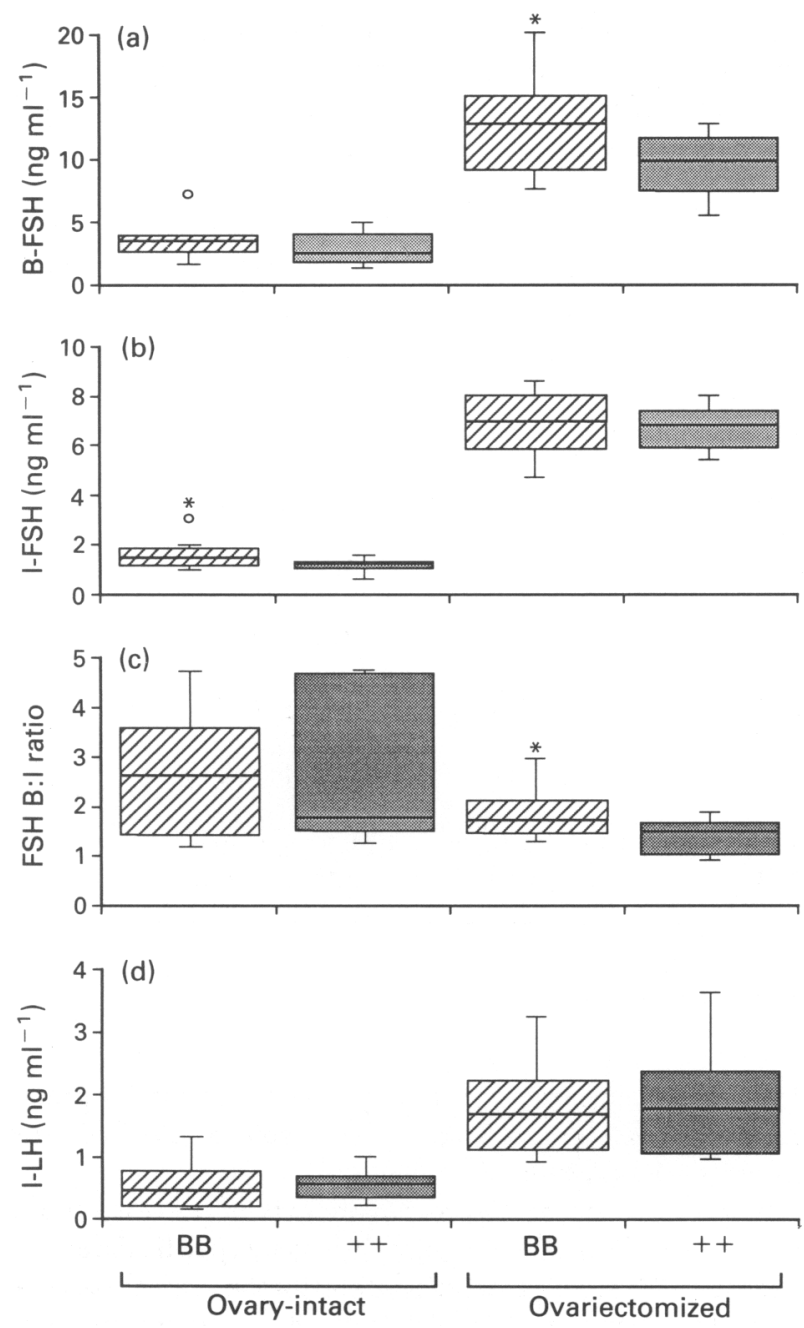

Fig. 3. Box and Whisker plots for overall group means for plasma (a) bioactive (B)FSH, (b) immunoreactive (I) FSH, (c) bioactive:immunoreactive (B:I) ratio for FSH and (d) immunoreactive $\mathrm{LH}(\mathrm{I}-\mathrm{LH})$ in ovaryintact and ovariectomized $\mathrm{BB}$ and ++ ewes. The ends of the vertical lines (whiskers) represent the maximum and minimum values, with open circles depicting outliers. The extremities of the box represent the upper and lower quartiles and the horizontal line through the box represents the median value. ${ }^{*}$ Significant $(P<0.05$, Student's $t$ test) effect of genotype within that ovary-state.

genotypic differences were noted in plasma I-LH concentrations following ovariectomy.

\section{Pituitary gonadotrophin contents or concentrations}

For B-FSH and I-FSH, there were no significant effects of either genotype or ovariectomy, although in both assays BB ewes tended to have higher contents or concentrations than did ++ ewes, and ovariectomized ewes tended to have higher values than did ovary-intact animals (Table 1). No changes due to genotype or ovariectomy were noted for the pituitary B:I ratio for FSH or the I-FSH:I-LH ratio. For I-LH, no significant differences between groups were noted, except that ovariectomized BB ewes had significantly $(P<0.05)$ higher pituitary LH contents (but not concentrations) than ovariectomized ++ ewes.
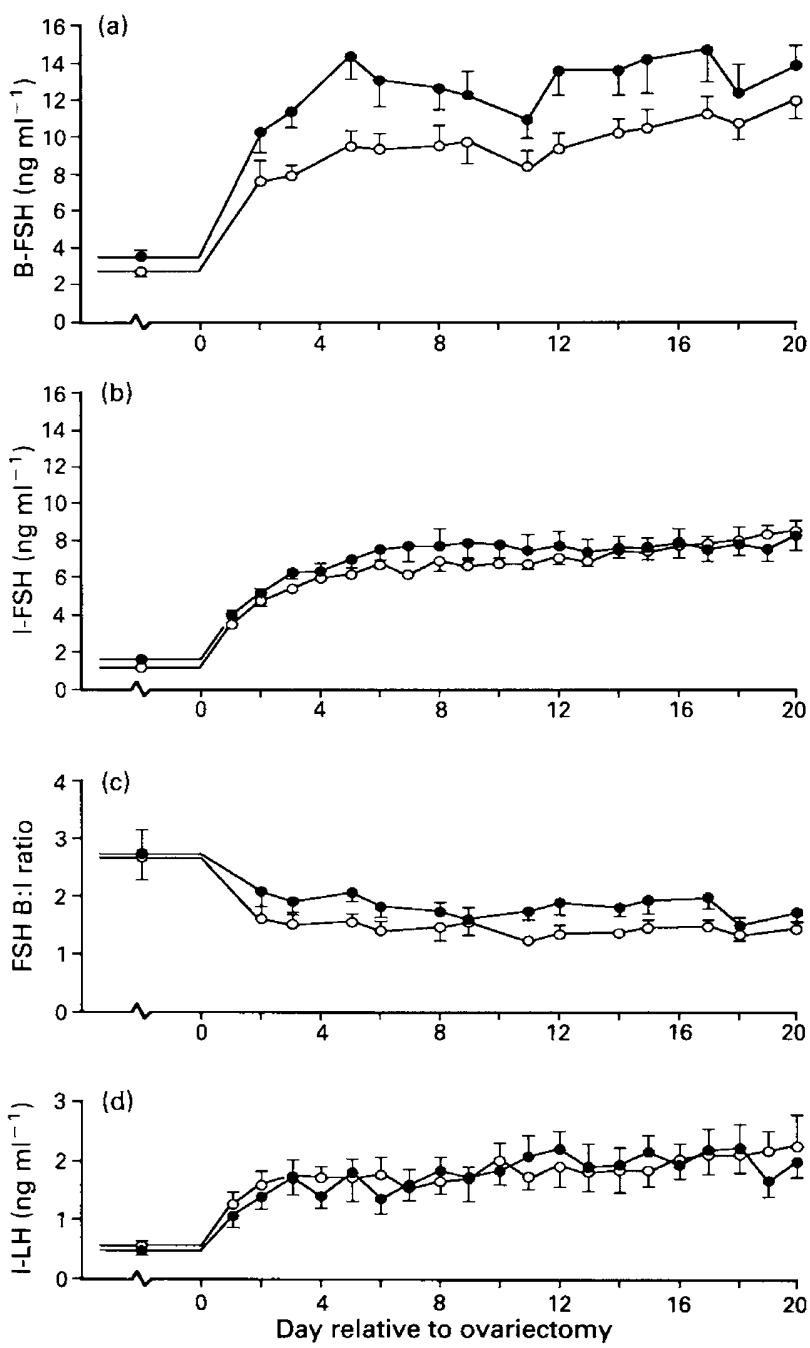

Fig. 4. Daily mean ( $\pm \mathrm{SEM} ; n=12$ per point) concentrations of plasma (a) bioactive (B)FSH, (b) immunoreactive (I)FSH, (c) bioactive: immunoreactive (B:I) ratios for $\mathrm{FSH}$ and (d) immunoreactive $\mathrm{LH}$ (I-LH) concentrations for $\mathrm{BB}(\boldsymbol{O})$ and $++(\bigcirc)$ ewes after ovariectomy. The values before ovariectomy represent the overall group mean ( \pm SEM) for that variable. Note that the axes scales for B-FSH and I-FSH are identical.

\section{Discussion}

Plasma concentrations of I-FSH increased after ovariectomy in ewes, as reported by Lahlou-Kassi et al. (1984), Martin et al. (1986) and Montgomery et al. (1987). Similarly, plasma B-FSH concentrations increased significantly and values were higher in both genotypes relative to the corresponding I-FSH concentration, i.e. the plasma B:I ratios were greater than unity. Nevertheless, the overall B:I ratios, irrespective of genotype, decreased significantly compared with ovary-intact values. To our knowledge, B-FSH and changes in B:I ratio have not been described previously for ovariectomized females, but there are some parallel data in the male. In a number of conditions that cause infertility in man, both serum B-FSH and I-FSH concentrations are higher than those in fertile men, whereas the serum 
Table 1. Pituitary gonadotrophin data for ovary-intact and ovariectomized Booroola ewes, consisting of mean ( \pm SEM) contents and concentrations of bioactive (B)FSH, immunoreactive (I)FSH and immunoreactive I-LH. Bioactive:immunoreactive (B:I) ratios for FSH and the I-FSH:I-LH ratios are also given

\begin{tabular}{|c|c|c|c|c|}
\hline \multirow[b]{2}{*}{ Variable } & \multicolumn{2}{|c|}{ Ovary-intact } & \multicolumn{2}{|c|}{ Ovariectomized } \\
\hline & $\mathrm{BB}(5)^{\mathrm{a}}$ & $++(5)$ & $\mathrm{BB}(12)$ & $++(12)$ \\
\hline $\begin{array}{l}\text { Pituitary weight } \\
\text { (g) }\end{array}$ & $0.62 \pm 0.08$ & $0.68 \pm 0.11$ & $0.74 \pm 0.06$ & $0.70 \pm 0.06$ \\
\hline $\begin{array}{l}\text { B-FSH content } \\
\text { ( } \mu \text { g per pituitary) }\end{array}$ & $54.3 \pm 7.1$ & $44.2 \pm 11.9$ & $86.2 \pm 11.4$ & $60.5 \pm 7.6$ \\
\hline $\begin{array}{l}\text { B-FSH concentration } \\
\text { ( } \mu \mathrm{g} \mathrm{mg}^{-1} \text { pituitary) }\end{array}$ & $0.09 \pm 0.01$ & $0.08 \pm 0.03$ & $0.12 \pm 0.01$ & $0.09 \pm 0.01$ \\
\hline $\begin{array}{l}\text { I-FSH content } \\
\text { ( } \mu \mathrm{g} \text { per pituitary) }\end{array}$ & $54.2 \pm 5.4$ & $41.2 \pm 4.8$ & $72.1 \pm 6.0$ & $56.0 \pm 5.8$ \\
\hline $\begin{array}{l}\text { I-FSH concentration } \\
\text { ( } \mu \mathrm{g} \mathrm{mg} \mathrm{m}^{-1} \text { pituitary) }\end{array}$ & $0.09 \pm 0.01$ & $0.07 \pm 0.02$ & $0.10 \pm 0.01$ & $0.09 \pm 0.01$ \\
\hline $\begin{array}{l}\text { I-LH content } \\
\text { ( } \mu \mathrm{g} \text { per pituitary) }\end{array}$ & $525.0 \pm 80.3$ & $443.8 \pm 60.1$ & $504.9 \pm 35.0^{*}$ & $389.3 \pm 25.5$ \\
\hline $\begin{array}{l}\text { I-LH concentration } \\
\left(\mu \mathrm{g} \mathrm{m}^{-1} \text { pituitary) }\right.\end{array}$ & $0.90 \pm 0.15$ & $0.70 \pm 0.09$ & $0.72 \pm 0.06$ & $0.59 \pm 0.05$ \\
\hline FSH B:I ratio & $1.03 \pm 0.15$ & $0.97 \pm 0.18$ & $1.18 \pm 0.10$ & $1.10 \pm 0.10$ \\
\hline 1-FSH:I-LH ratio & $0.11 \pm 0.01$ & $0.10 \pm 0.03$ & $0.15 \pm 0.01$ & $0.15 \pm 0.01$ \\
\hline
\end{tabular}

Number of animals is given in parentheses.

*Significant $(P<0.05$, Student's $t$ test) difference between ovariectomized BB and ++ ewes.

B:I ratios are lower (Wang et al., 1987; Jockenhövel et al., 1989). Taken together with the results of our study, these data suggest that in the absence of gonadal factors, such as steroids and inhibin, the net bioactivity of FSH isoforms in the peripheral circulation is decreased, even though absolute concentrations of B-FSH and I-FSH increase. An important consideration is that in vitro measures of B-FSH take no account of differential clearance rates of FSH isoforms from the circulation. It is known that the half-life of FSH in ewes is increased following ovariectomy (Fry et al., 1987; Robertson et al., 1991). It is therefore conceivable that the increases in the bioactivity of FSH isoforms following ovariectomy are offset to a degree by the increased half-life of FSH in the circulation.

Few differences were observed in pituitary FSH contents or concentrations following ovariectomy. In both genotypes, B-FSH and I-FSH contents or concentrations tended to be higher following ovariectomy, but the difference was not significant; this trend is consistent with the findings of Moss et al. (1981), although in their study the differences were statistically significant. An increase in pituitary FSH measured by radioreceptor assay (R-FSH) was observed following ovariectomy in rats (Robertson et al., 1982), and in that study the pituitary receptor: immunoreactive ratio was significantly higher in ovariectomized females than in pro-oestrous females. At least in rats (Robertson et al., 1982) and ewes (Robertson et al., 1991), the distribution of pituitary isoforms of FSH does not appear to be affected markedly by the lack of gonads, although in heifers ovariectomy results in a shift to more basic isoforms (Stumpf et al., 1992). However, the apparent differences between species may reflect the different methodologies used to separate the isoforms of FSH from pituitary extracts, and the time after ovariectomy that the glands were collected. In any case, the fact that the pituitary
B:I ratio for FSH was not affected by ovariectomy in the present study suggests that profound shifts in isoform distribution of FSH were not occurring.

The present data confirmed the findings of previous studies on ovary-intact Booroola ewes, in that gene specific differences in plasma FSH could be detected. In common with these other studies (McNatty et al., 1987; McNatty et al., 1989), most of the differences were small and were not always statistically significant. For instance, the overall means for the plasma B-FSH concentrations of $\mathrm{BB}$ and ++ ewes were not significantly different, yet the $\mathrm{BB}$ ewes had a higher mean concentration of B-FSH on 13 of the 17 days of the oestrous cycle. In contrast, no genotypic differences in plasma B:I ratio were noted before ovariectomy. This is consistent with data from other studies, in which there were no differences in the half-life of endogenous FSH between ovary-intact B + and ++ ewes (Fry et al., 1987), and the chromatofocusing profiles for pituitary FSH were similar between carriers and non-carriers of the $\mathrm{Fec}^{\mathrm{B}}$ gene (Robertson et al., 1984). In the present study, the overall mean concentrations of I-FSH were significantly higher in the ovaryintact BB ewes, as were those for B-FSH (although not significantly so). These data suggest that in the ovary-intact ewes, there are quantitative differences in plasma FSH between genotypes but few differences in the distribution and bioactivity of FSH isoforms. Despite the fact that these genotypic differences are small, they may be of physiological significance, as modest $(<15 \%)$ increases in plasma I-FSH concentrations can result in significantly higher ovulation rates (McNatty et al, 1985; Henderson et al., 1988; Montgomery et al., 1992).

An important finding of this study was that there were consistent differences between genotypes in plasma B-FSH concentrations after ovariectomy; mean plasma concentrations of 
B-FSH were higher in the BB ewes on all days, and the overall mean concentrations were significantly higher compared with the ++ group. The plasma B:I ratio for FSH was also higher in the $\mathrm{BB}$ genotype, suggesting that the net bioactivity of the FSH isoforms in this group was greater than that of the noncarrier ewes. This is unlikely to be affected by differences in the clearance rates of these isoforms, as Fry et al. (1987) found no differences in the half-life of endogenous FSH in ovariectomized $\mathrm{B}+$ or ++ Booroola ewes.

Although overall plasma B-FSH concentrations before ovariectomy were not significantly different in $\mathrm{BB}$ ewes than in the ++ group, $\mathrm{BB}$ ewes had significantly higher mean daily concentrations of B-FSH $(P<0.05)$ and I-FSH $(P<0.01)$ on days 13-16 of the cycle. Although genotypic differences in plasma I-FSH concentrations over this period have been shown by McNatty et al. (1989, 1991 and 1992), this is the first time that a similar pattern has been described for B-FSH. We suggest that the high plasma concentrations of FSH over days 13 to 16 of the oestrous cycle is responsible for the higher ovulation rate observed in carriers of the $\mathrm{Fec}^{\mathrm{B}}$ gene, as it is known that plasma concentrations of FSH over this period influence the subsequent ovulation rate (Henderson et al., 1988). However, these data do not explain some of the other gene-specific effects (for example ovulation of follicles at a smaller size) that have also been observed in Fec ${ }^{\mathrm{B}}$ carriers (McNatty et al, 1991).

In contrast to previous findings, no gene-specific differences were noted for the pituitary contents or concentrations of FSH before or after ovariectomy. Robertson et al. (1984) reported that the pituitary contents for R-FSH were significantly higher in ovary-intact $\mathrm{BB}$ and $\mathrm{B}+$ than in ++ ewes. In addition, these workers found that the pituitary FSH:LH ratio was significantly higher in $\mathrm{Fec}^{\mathrm{B}}$ carriers on day 3 of the oestrous cycle. In the present study, no genotypic differences in the pituitary FSH: LH ratio were found at days 10 to 13 or after ovariectomy. In another earlier study, $\mathrm{Fec}^{\mathrm{B}}$ carriers had significantly higher pituitary I-FSH contents and concentrations at day 3 (Bindon, 1984); in the present study gene-specific differences were not noted, although the pituitary I-FSH contents or concentrations tended to be higher in the $\mathrm{BB}$ group than in the ++ ewes. Differences in the radioimmunoassays used and the stage of the oestrous cycle at which the pituitary glands were collected may explain the lack of concordance between our findings and the previous studies.

No gene-specific differences were noted for I-LH in either plasma or pituitary samples, except for pituitary I-LH contents between ovariectomized $\mathrm{BB}$ and ++ ewes. This difference between the genotypes was not reflected in the pituitary I-LH concentrations. Previously the only gene-specific differences recorded for I-LH have been in the pulse amplitudes of plasma LH (McNatty et al., 1987).

The pattern of plasma B-FSH was remarkably consistent between genotypes across the oestrous cycle, except between days 13 and 16 as mentioned above. In particular, there appeared to be discrete peaks of B-FSH activity over a period of a few days during the luteal phase; this pattern was also observed in the luteal phase of gorillas (Dahl et al., 1987) and rhesus monkeys (Matteri et al., 1992). Although details of follicular growth were not recorded in this study, these 'waves' of B-FSH may be related to the recruitment and selection of follicles for the next ovulation, but at this stage this notion is only speculation. We also detected no changes in the plasma B:I ratio for FSH across the oestrous cycle. Similar findings have been reported for the menstrual cycle of women (Jia et al., 1986; Padmanabhan et al., 1988; Reddi et al., 1990) and monkeys (Matteri et al., 1992), except that in the latter three studies there was an increase in the B:I ratio for FSH at the time of the mid-cycle LH surge. As the present study was not designed to address this issue, further investigation into cyclical changes in plasma B:I ratio in ewes is warranted.

In conclusion, ovariectomy caused dramatic increases in the concentrations of plasma B-FSH and I-FSH concentrations, with a corresponding decrease in plasma B:I ratio, irrespective of genotype. Effects specific to the $\mathrm{Fec}^{\mathrm{B}}$ gene were found both before and after ovariectomy; plasma FSH concentrations were higher in $\mathrm{Fec}^{\mathrm{B}}$ carriers for I-FSH before ovariectomy, and B-FSH after ovariectomy; plasma $B: I$ ratios were significantly higher in BB ewes compared with ++ ewes after ovariectomy. In the pituitary gland, there were no significant effects of genotype or ovariectomy on B-FSH or I-FSH contents or concentrations. These findings show that qualitative as well as quantitative measures of plasma FSH can be influenced by gonadal state and the presence of the Fec ${ }^{\mathrm{B}}$ gene, whereas pituitary FSH is not affected to a significant extent.

The authors thank K. Ball, D. Heath, L. Shaw and L. Condell for excellent technical assistance, $K$. Skevington for the care and provision of the rats used in the FSH bioassay, and K. Isaacs for the pedigree records of the $\mathrm{Fec}^{\mathrm{B}}$ genotypes. We are grateful to the NHPP for the provision of the hormone standards and antibodies used in this study.

\section{References}

Bindon BM (1984) Reproductive biology of the Booroola Merino sheep Australian Joumal of Biological Sciences 37 163-189

Dahl KD, Czekala NM, Lim P and Hsueh AJW (1987) Monitoring the menstrual cycle of humans and lowland gorillas based on urinary profiles of bioactive follicle-stimulating hormone and steroid metabolites Joumal of Clinical Endocrinology and Metabolism 64 486-493

Davis GH, Montgomery GW, Allison AJ, Kelly RW and Bray AR (1982) Segregation of a major gene influencing fecundity in progeny of Booroola sheep New Zealand Joumal of Agricultural Research 25 525-529

Emerson JD and Strenio J (1983) Boxplots and batch comparison. In Understanding Robust and Exploratory Data Analysis, pp 62-96 Eds DC Hoaglin, F Mosteller and JW Tukey. John Wiley \& Sons, Inc., New York

Fry RC, Cahill LP, Cummins JT, Bindon BM, Piper LR and Clarke IJ (1987) The half-life of follicle-stimulating hormone in ovary-intact and ovariectomized Booroola and control Merino ewes Journal of Reproduction and Fertility 81 611-615

Henderson KM, Savage LC, Ellen RL, Ball K and McNatty KP (1988) Consequences of increasing or decreasing plasma FSH concentrations during the preovulatory period in Romney ewes Journal of Reproduction and Fertility 84 187-196

Jia X-C, Kessel B, Yen SSC, Tucker EM and Hsueh AJW (1986) Serum bioactive follicle-stimulating hormone during the human menstrual cycle and in hyperand hypogonadotropic states: application of a sensitive granulosa cell aromatase bioassay Journal of Clinical Endocrinology and Metabolism 62 1243-1249

Jockenhövel F, Khan SA and Nieshlag E (1989) Diagnostic value of bioactive FSH in male infertility Acta Endocrinologica 121 802-810

Lahlou-Kassi A., Schams D and Glatzel P (1984) Plasma gonadotrophin concentrations during the oestrous cycle and after ovariectomy in two breeds of sheep with low and high fecundity Joumal of Reproduction and Fertility $\mathbf{7 0}$ $165-173$ 
McNatty KP, Hudson NL, Henderson KM, Lun S, Heath DA, Gibb M, Ball, K McDiarmid JM and Thurley DC (1984) Changes in gonadotrophin secretion and ovarian antral follicular activity in seasonally breeding sheep throughout the year Journal of Reproduction and Fertility 70 309-321

McNatty KP, Hudson N, Gibb M, Ball K, Henderson KM, Heath DA, Lun S and Kieboom LE (1985) FSH influences follicle viability, oestradiol biosynthesis and ovulation rate in Romney ewes Joumal of Reproduction and Fertility $\mathbf{7 5}$ $121-131$

McNatty KP, Hudson N, Henderson KM, Gibb M, Morrison L, Ball $\mathbf{K}$ and Smith P (1987) Differences in gonadotrophin concentrations and pituitary responsiveness to $\mathrm{GnRH}$ between Booroola ewes which were homozygous $(\mathrm{FF})$, heterozygous $(\mathrm{F}+)$ and non-carriers $(++)$ of a major gene influencing their ovulation rate Journal of Reproduction and Fertility 80 577-588

McNatty KP, Fisher M, Collins F, Hudson NL, Heath DA, Ball K and Henderson KM (1989) Differences in the plasma concentrations of FSH and LH in ovariectomized Booroola FF and ++ ewes Journal of Reproduction and Fertility 85 705-713

McNatty KP, Henderson KM, Fleming IS, Clarke IJ, Bindon BM, Piper LR, O'Shea T, Hillard MA and Findlay JK (1991) The physiology of the Booroola ewe. In Major Genes for Reproduction in Sheep, pp 105-124 Eds JM Elsen, L Bodin and I Thimonier. Institut National de la Recherche Agronomique, Paris

McNatty KP, Heath DA, Hudson NL, Ball K and Condell L (1992) Immunoreactive inhibin concentrations in ovarian and peripheral venous plasma and follicular fluid of Booroola ewes which were homozygous carriers or non-carriers of the $\mathrm{Fec}^{\mathrm{B}}$ gene Joumal of Reproduction and Fertility 95 489-502

Martin GB, Wallace JM, Taylor PL, Fraser HM, Tsonis CG and McNeilly AS (1986) The roles of inhibin and gonadotrophin-releasing hormone in the control of gonadotrophin secretion in the ewe Journal of Endocrinology 111 287-296

Matteri RL, Bridson WE, Dierschke DJ, Wegner FH and Durning M (1992) The secretion of bioactive and immunoreactive follicle-stimulating hormone (FSH) and luteinizing hormone (LH) throughout the menstrual cycle of the rhesus monkey (Macaca mulatta) American Journal of Primatology 26 243-257

Montgomery GW, Crosbie SF, Martin GB and Pelletier J (1984) Changes in the clearance rate of immunoreactive $\mathrm{LH}$ after ovariectomy in lle-de-France ewes. In Reproduction in Sheep, pp 23-25 Eds DR Lindsay and DT Pearce. Australian Academy of Science, Canberra
Montgomery GW, Martin GB, Blanc MR and Pelletier J (1987) Season influences FSH concentrations in ovariectomized Ile-de-France ewes Journal of Reproduction and Fertility 80 271-277

Montgomery GW, McNatty KP and Davis GW (1992) Physiology and molecular genetics of mutations that increase ovulation rate in sheep Endocrine Reviews 13 309-328

Moss GE, Crowder ME and Nett TM (1981) GnRH-receptor interaction. VI. Effect of progesterone and estradiol on hypophyseal receptors for $\mathrm{GnRH}$, and serum and hypophyseal concentrations of gonadotropins in ovariectomized ewes Biology of Reproduction 25, 938-944

Padmanabhan V. Chappel SC and Beitins IZ (1987) An improved in vitro bioassay for follicle-stimulating hormone (FSH) suitable for measurement of FSH in unextracted human serum Endocrinology 121 1089-1098

Padmanabhan V, Lang LL, Sonstein J, Kelch RP and Beitins IZ (1988) Modulation of serum follicle-stimulating hormone bioactivity and isoform distribution by estrogenic steroids in normal women and in gonadal dysgenesis Journal of Clinical Endocrinology and Metabolism 67 465-473

Reddi K, Wickings EJ, McNeilly AS, Baird DT and Hillier SG (1990) Circulating bioactive follicle stimulating hormone and immunoreactive inhibin levels during the normal human menstrual cycle Clinical Endocrinology 33 547-557

Robertson DM, Foulds LM and Ellis S (1982) Heterogeneity of rat pituitary gonadotropins on electrofocusing: differences between sexes and after castration Endocrinology 111 385-391

Robertson DM, Ellis S, Foulds LM, Findlay JK and Bindon BM (1984) Pituitary gonadotrophins in Booroola and control Merino sheep Journal of Reproduction and Fertilify 71 189-197

Robertson DM, Foulds LM, Fry RC, Cummins JT and Clarke IJ (1991) Circulating half-lives of follicle-stimulating hormone and luteinizing hormone in pituitary extracts and isoform fractions of ovariectomized and intact ewes Endocrinology 129 1805-1813

Stumpf TF, Roberson MS, Wolfe MW, Zalesky DD, Cupp AS, Werth LA, Kojima N, Hejl K, Kittok RJ, Grotjan HE and Kinder JE (1992) A similar distribution of gonadotropin isohormones is maintained in the pituitary throughout sexual maturation in the heifer Biology of Reproduction 46 $442-450$

Wang C, Dahl KD, Lueng A, Chan SYW and Hsueh AJW (1987) Serum bioactive follicle-stimulating hormone in men with idiopathic azoospermia and oligospermia Journal of Clinical Endocrinology and Metabolism 65 629-633

Zar JH (1974) Biostatistical analysis Prentice-Hall, Inc., Englewood Cliffs, New Jersey 